Pobrane z czasopisma Annales H - Oeconomia http://oeconomia.annales.umcs.pl Data: 26/04/2023 15:47:21

DOI:10.17951/h.2015.59.3.7

\begin{tabular}{lc}
\hline & A N N A L E S \\
UNIVERSITATIS MARIAE CURIE-SKŁODOWSKA \\
LUBLIN - POLONIA \\
VOL. XLIX, 3 & SECTIO H
\end{tabular}

Koźmiński University, College of Management and Finance

Department of Marketing Superdrob, Department of Foreign Trade - England and Ireland

\author{
MIROSŁAW ANTONOWICZ \\ ADAM ARASZKIEWICZ \\ maaw@kozminski.edu.pl
}

\title{
The Role of the Port of Busan in South Korea International Logistics
}

Rola Portu Busan w logistyce międzynarodowej Korei Południowej

Keywords: international logistics, transport corridor, logistics centre.

Slowa kluczowe: logistyka międzynarodowa, korytarz transportowy, centrum logistyczne.

JEL Code: F6, M3, R4

\section{Introduction}

Advancing globalization of the world economy has affected countries that were still considered hermetically sealed in the twentieth century, such as Japan, China, and South Korea. Nowadays, global corporations as well as governments include marketing, production, and logistics in their strategic plans, apart from technology. It is because of the fact that the logistics chain itself, by facilitating international trade, can be a source of competitive advantage (Coyle et al. 2002, p. 615). The term International Logistics can be described as the process of planning, implementing and controlling the flow of goods between countries (Koźmiński, 1999, p. 158; Gołembska, 2014, p. 49). As noted by Gołembska et al. (2014, p. 7), the phenomenon of international logistics, as a separate field of knowledge within the functioning of international business, lies in the fact that the contemporary business or multinational corporations do not compete with each other only by means of price and 
quality but also through innovative logistic solutions. Clearly, such solutions become a key element in the success of companies in the era of globalization (Szymczak, 2014, p. 41). Due to geographical and geopolitical location, Asian countries such as China, Japan, and South Korea, together with their corporations, recognize an opportunity in shifting to the areas of logistic activity. Such a shift, realized through the improvement of transport infrastructure and logistic processes, may enhance their position or role in the international trade. The aim of the article is to present, on the example of one chosen logistic port centre, the importance of international logistics for economic development and the building of South Korea's logistic participation on the global market.

\section{The place of South Korea in the international logistics}

South Korea is a highly industrialized country with a strong sector of new technologies. It occupies 13th place on the list of the major economic powers of the world. The power and status of the Korean economy is confirmed on the graph representing recent changes in the GDP, in the level of unemployment and in the financial balance including inflation. According to the provided data, Korea is in a group of countries achieving rates above average amongst the countries belonging to the OECD ${ }^{1}$.

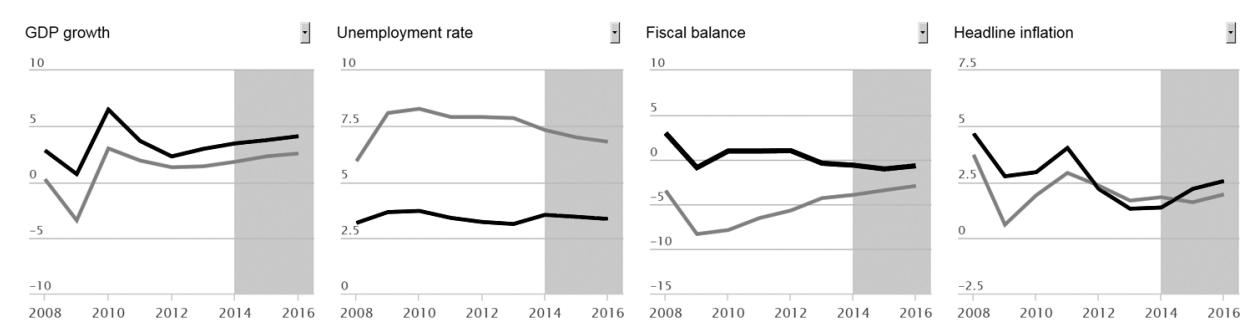

Chart 1 . The strength of Korean economy as against selected measurements

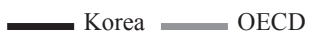

Source: OECD official website: http://www.oecd.org/economy/korea-economic-forecast-summary.htm [Date of access: May 20, 2014]

However, the economic and logistic situation of South Korea is very complicated due to geopolitics and economy of the north-east Asian region. This region with huge internal market and over 1.5 billion people is home to three leaders of global economic growth: China, Japan, and South Korea itself. At the beginning of the twenty first century, the region's total production amounted to about $21 \%$ of the world

\footnotetext{
1 OECD - Organisation for Economic Co-operation and Development
} 
production and, according to the forecasts for 2020, it will increase to approximately $30 \%$ (KITA, 2009, p. 17). South Korea is in the centre of the region, "sandwiched" between two great neighbours and, therefore, has to fight for its position as an Asian logistics centre. The logistics centre is a designated area which includes all activities related to the logistic distribution and transportation of goods, both in the domestic and international sector (often performed by different operators) (Miklińska, 2008, p.75). In order to ensure the principles of free competition, the centre must provide the access to various modes of transport, e.g. rail, road, or sea to companies involved in the business, in order to allow for the most effective carriage and handling of goods. The position of the north-east Asian region in the world trade is growing. This is illustrated by Figure 1 which represents the percentage of export and import in the world trade in 2005 and forecast for trade in 2015.

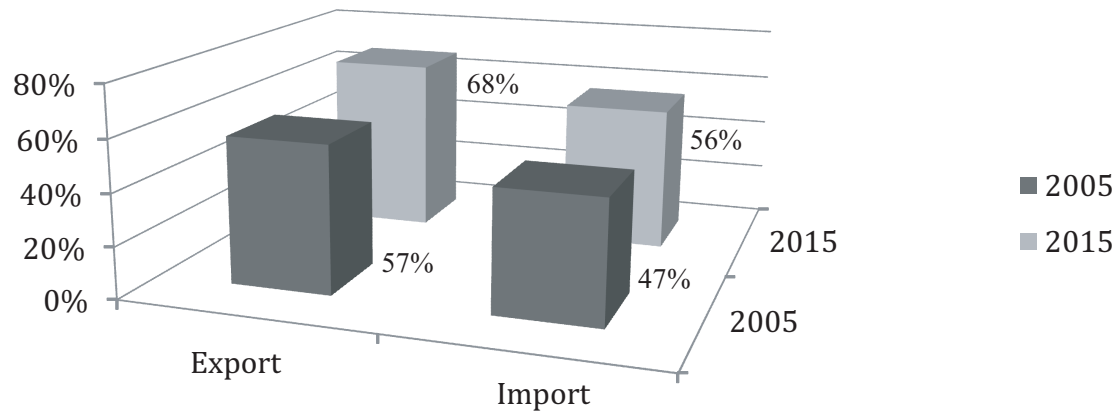

Figure 1. Share of Northeast Asia Import \& Export Trade (2005 \& 2015)

Source: author's presentation on the basis of Jin-Sun-Shin, Northeast Asia Container Trade and Busan Port, Busan Port Authority, 2014, p. 4

In the abovementioned period, the share of the rest of the world will fall by $11 \%$ in terms of exports and 9\% for imports ${ }^{2}$. The improving position of China, Japan and South Korea is also confirmed by the growing percentage of exports in their Gross Domestic Product. In South Korea, the share of $3.2 \%$ of GDP $^{3}$ in 1960 increased to $53.9 \%$ of GDP in 2013, Japan increased the percentage from $10.7 \%$ to $16.2 \%$ of GDP in 2013 and China from $8.4 \%$ in 1982 to $26.4 \%$ of GDP in $2013^{4}$. The importance of the region can also be confirmed by the data from the World Bank's Logistics

2 Poland's 26.3\% GDP from 1990 rose to $46.1 \%$ in 2013.

3 Gross domestic product (GDP) is defined by the Organisation for Economic Co-operation and Development (OECD) as "an aggregate measure of production equal to the sum of the gross values added by all resident institutional units engaged in production (plus any taxes, and minus any subsidies on products not included in the value of their outputs)."

4 Export of services 1960-2013. Source: http://databank.worldbank.org/data/home.aspx [Date of access: December 15, 2014]. 
Performance Index (LPI 2014) which defines logistics efficiency parameters of a country. The Republic of Korea takes the 21 st place among 155 countries surveyed. Ranking of logistic efficiency for selected countries in the north-east Asian countries in 2014 is shown in Table 1.

The efficiency ratio is used to analyse the logistics performance of a country's logistic environment. The indicator was created to recognize the role of logistics in international trade (Murphy et al., 2011, p. 398). In order to establish the position of a country, the following six dimensions of logistics are examined: the efficiency of the customs clearance process, the quality of transport infrastructure, price competitiveness in the provision of goods, the quality of logistic services, on-time delivery of consignments within the agreed delivery time, transparency of delivery and tracking (Antonowicz, 2014, p. 98).

Table 1. Ranking of logistic efficiency of selected countries including the Republic of Korea

\begin{tabular}{|c|c|c|c|c|c|c|c|c|c|}
\hline Country & Year & $\frac{\underline{\text { LPI }}}{\underline{\text { Rank }}}$ & $\underline{\text { LPI }}$ & $\underline{\text { Customs }}$ & $\underline{\text { Infrastructure }}$ & $\frac{\text { International }}{\underline{\text { shipments }}}$ & $\begin{array}{c}\frac{\text { Logistics }}{\text { competence }} \\
\underline{\text { compen }}\end{array}$ & $\begin{array}{c}\frac{\text { Tracking }}{\underline{\&}} \\
\text { tracing }\end{array}$ & $\underline{\underline{\text { Time- }}}$ \\
\hline Germany & 2014 & 1 & 4.12 & 4.10 & 4.32 & 3.74 & 4.12 & 4.17 & 4.36 \\
\hline Netherlands & 2014 & 2 & 4.05 & 3.96 & 4.23 & 3.64 & 4.13 & 4.07 & 4.34 \\
\hline Belgium & 2014 & 3 & 4.04 & 3.80 & 4.10 & 3.80 & 4.11 & 4.11 & 4.39 \\
\hline $\begin{array}{c}\text { United } \\
\text { Kingdom }\end{array}$ & 2014 & 4 & 4.01 & 3.94 & 4.16 & 3.63 & 4.03 & 4.08 & 4.33 \\
\hline Singapore & 2014 & 5 & 4.00 & 4.01 & 4.28 & 3.70 & 3.97 & 3.90 & 4.25 \\
\hline Sweden & 2014 & 6 & 3.96 & 3.75 & 4.09 & 3.76 & 3.98 & 3.97 & 4.26 \\
\hline Norway & 2014 & 7 & 3.96 & 4.21 & 4.19 & 3.42 & 4.19 & 3.50 & 4.36 \\
\hline Luxembourg & 2014 & 8 & 3.95 & 3.82 & 3.91 & 3.82 & 3.78 & 3.68 & 4.71 \\
\hline \begin{tabular}{l|} 
United \\
States \\
\end{tabular} & 2014 & 9 & 3.92 & 3.73 & 4.18 & 3.45 & 3.97 & 4.14 & 4.14 \\
\hline Japan & 2014 & 10 & 3.91 & 3.78 & 4.16 & 3.52 & 3.93 & 3.95 & 4.24 \\
\hline $\begin{array}{c}\text { Hong Kong, } \\
\text { China }\end{array}$ & 2014 & 15 & 3.83 & 3.72 & 3.97 & 3.58 & 3.81 & 3.87 & 4.06 \\
\hline Taiwan & 2014 & 19 & 3.72 & 3.55 & 3.64 & 3.71 & 3.60 & 3.79 & 4.02 \\
\hline Italy & 2014 & 20 & 3.69 & 3.36 & 3.78 & 3.54 & 3.62 & 3.84 & 4.05 \\
\hline Korea, Rep. & 2014 & 21 & 3.67 & 3.47 & 3.79 & 3.44 & 3.66 & 3.69 & 4.00 \\
\hline Malaysia & 2014 & 25 & 3.59 & 3.37 & 3.56 & 3.64 & 3.47 & 3.58 & 3.92 \\
\hline China & 2014 & 28 & 3.53 & 3.21 & 3.67 & 3.50 & 3.46 & 3.50 & 3.87 \\
\hline Poland & 2014 & 31 & 3.49 & 3.26 & 3.08 & 3.46 & 3.47 & 3.54 & 4.13 \\
\hline
\end{tabular}

Source: study based on the Word Bank, 2014

Transfer of goods across borders is the primary determinant for the development of international logistics and the direct result of the development of international

5 The Republic of Korea maintained its 21st position in the study in relation to the study of 2012. Japan is ranked 10th in the survey (a decrease compared to the 2012 survey by 2 positions). China ranks 28 th (down by 2 positions in relation to the study from 2012), Poland is ranked 31st (down by 1 position in relation to the 2012 survey). 
trade as well as dispersion of economic activities and trade (Rymarczyk, 2012, p. 338). This implies the need for integration of sourcing, production and marketing between companies from different continents (Gołembska et al., 2004, p. 9).

This is possible through the use of appropriate tools of international logistics, including those surveyed by the World Bank. These tools include the use of various means of transport systems and infrastructure, e.g. warehouse space and tools for the effective management of information flow. Growing importance of Asian countries has led to the need to identify the main routes of trade both between and within continents. The main transport route is called the Corridor. The transport corridor is a continuous sequence of transport infrastructure of international importance with transport nodes along its length (e.g. logistic centres) that meet certain specifications (Wielądek, 2014, p. 695). This corridor should be enriched with all kinds of legal, organizational and technological solutions in order to direct the stream of goods through it (Latuszyńska, 2004. pp. 41-49). One of the most important consequences of the development of trade between Asia and Europe is growth in the movement of specialized container ships between the continents. The ports owe their logistic nature mainly to their location, infrastructure and facilities. The role of ports themselves has increased, mainly because of the following reasons:

- Technical factors such as: new types of ships ${ }^{6}$ which, in order to push the development of intermodal transport further, were forced to stop in fewer locations. This resulted in changes of operator preferences; operators started to retain their ships in one mega port or a particular business area, as they were only large enough to handle loads carried by these vessels (Murphy et al., 2011, p. 393). Moreover, the services to the ever-growing ships could be provided only by ports that were ready for radical changes (improvements and reconstruction) and associated costs. This naturally reduced the number of ports that could compete with one another;

- The process of globalization has contributed as well by changing the structure of production and distribution. According to E. Cziomer (Cziomer, 2000, p. 3), globalization is the process that occurs in the world economy, primarily characterized by intensification of mobilization and movement of goods, capital and labour on a global scale. Globalization is one of the main factors responsible for the dynamic economic development of East Asia. In order to move goods faster, on schedule and in more intense flow, investment from these states and private enterprises were required so that the logistics centres that make up the global network of intercontinental connections could have been developed.

According to the Korean International Trade Association (Logistics in Korea, 2009 , p. 16), only the regions that have the best logistic infrastructure, capable of

${ }^{6}$ For example, the class of Triple E ships which are $400 \mathrm{~m}$ long. Even though they are merely $3 \mathrm{~m}$ longer and 4 meters wider than the class of E ships, the former can carry over 2500 TEU more on board than the latter, i.e. about 18000 containers in total. 
delivering efficient logistics services that meet the highest requirements of customers can now fight for the title of global logistic centres. A logistic centre acts as a database that provides services to neighbouring areas in the global system connecting regional economic areas and is a gateway to the region. A logistic centre acts as a fortress in which multinational companies can set up their headquarters and add value to the logistic service such as packaging, assembly, or production of goods. Several ports are fighting for the position of the main logistic centre in north-east Asia, among others, the port of Busan.

\section{The port of Busan in South Korea's Logistics}

The port of Busan is located on the south-eastern tip of the Korean peninsula. It is located more than 110 nautical miles southeast of the Japanese port of Kitakyushu. Its deep and tidal conditions have transformed it into the largest port in Korea and the fifth in the world. The results for 2011 are presented in Table 2.

Table 2. The largest ports in the world in 2011

\begin{tabular}{|c|c|c|c|c|}
\hline Container traffic & The total freight traffic & Port & Country & TEU million \\
\hline 1 & 1 & Shanghai & China & 31.7 \\
\hline 2 & 2 & Singapore & Singapore & 29.9 \\
\hline 3 & 10 & Hong Kong & China & 24.4 \\
\hline 4 & 15 & Shenzhen & China & 22.6 \\
\hline 5 & 9 & Busan & South Korea & 16.2 \\
\hline 10 & 4 & Rotterdam & Holland & 11.9 \\
\hline
\end{tabular}

Source: inzynieria.com: http://drogi.inzynieria.com/cat/19/art/35582/lista-najwiekszych-morskich-portow kontenerowych\#ixzz3NxQzFzw3 [Date of access: December 5, 2015]

How did Busan port manage to acquire such a high position? It was the beginning of 1990s when the international attention was caught by two phenomena. The first was the rapid growth of port infrastructure in China. The second was the dynamic development of the port of Busan (ESCAP, 2005, pp. 1-10). The Korean government, having considered all external conditions, decided to act as the manager of the majority of the Korean ports, aiming at further expansion of their logistic functions and strengthening their competitive advantage (Lee, 2010, pp. 8-10). Koreans knew that, in order to have a realistic chance of achieving the status of the logistic centre in north-east Asian region, they needed to develop at least one such a centre. At the end of the twentieth century they passed an act under which three duty-free zones in the ports of Busan, Gwangyang, and Incheon were set up (Ducruet et al., 2006, p. 9).

The purpose of such duty-free zones creation was to transform the Korean major container ports into north-east Asia logistic centres through the promotion of the international flow of goods, attraction of foreign investment, and stimulation of economic growth of the city through the development of the port. The New Port 
of Busan with an annual handling capacity of more than 8 million containers was completed in 2011 as the final result of the plan initiated 20 years earlier. The wellequipped port achieved the status of a mega port, which was supposed to help to redirect more traffic of container ships moving along the major shipping routes to the port. The advantage of the Busan lies in its strategic location as it lies at the crossroads of north-eastern China, Japan and Russia and at the major transport corridor to Europe and America. This is confirmed by Hayuth and Fleming (Hayuth et al., 1994, pp. 187-193) as in their opinion, the Port Busan owes success to its excellent location on the main transport route running north-south from Japan to Singapore, and at the same time being part of the trans-pacific corridor. The map Number 1 represents location of Busan in the context of the main global transport corridors responsible for the movement of goods around the world.

The industries such as: electronic, automobile, ceramic, paper, chemical, metal shipbuilding, and hi-tech play an important role in the economy of the city and the port itself ${ }^{7}$. Busan city, with 8 million inhabitants and their high purchasing power and expectations, is a powerful customer base, often considered as an ideal market for testing new technologies and products. These products often come from a free economic zone where R\&D facilities are developed thanks to favourable tax regulations. The zone covers an area of $81 \mathrm{~km}$, and its expansion is scheduled until 2020. As a result of these business-facilitating government actions, the role and importance of the port of Busan is growing and allows the port to take part in the competition for the most important logistic centre in the north of Asia in the twenty first century (Mindur, 2008, p. 455).

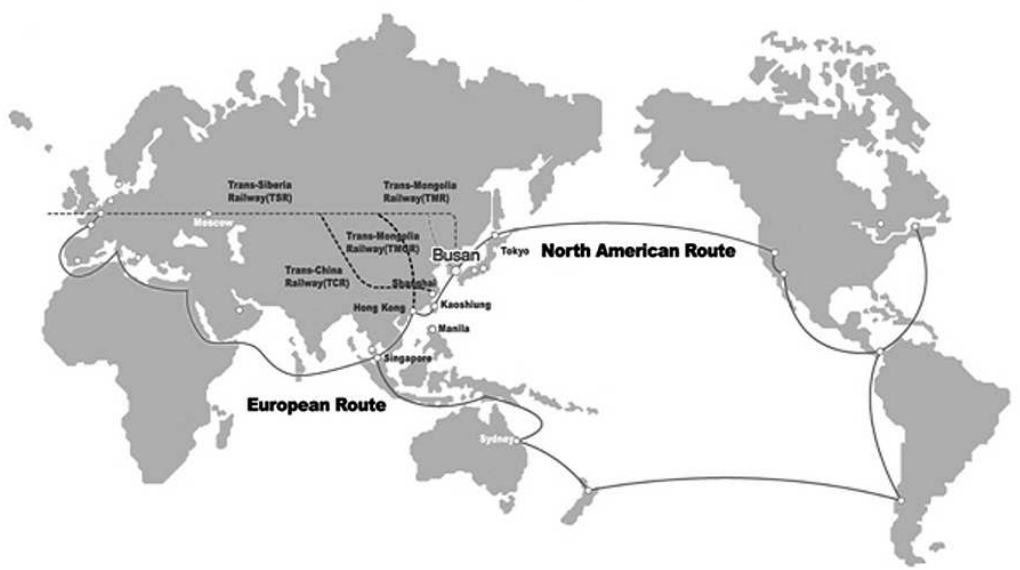

Map 1. Main transport corridors

Source: Busan Economic Promotion Agency Busan International Promotion Centre: http://www.bifc.kr/eng/sub02/ sub02_01.asp [Date of access: December 1, 2015]

7 Encyclopaedia Britannica: http://www.britannica.com/EBchecked/topic/484254/Pusan [Date of access: October 24, 2014]. 
The position of Busan is confirmed by the size of TEUs ${ }^{8}$ handled in the port and the share market in relation to other Korean ports. This is illustrated by Figures 3 and 4.

mln TEU

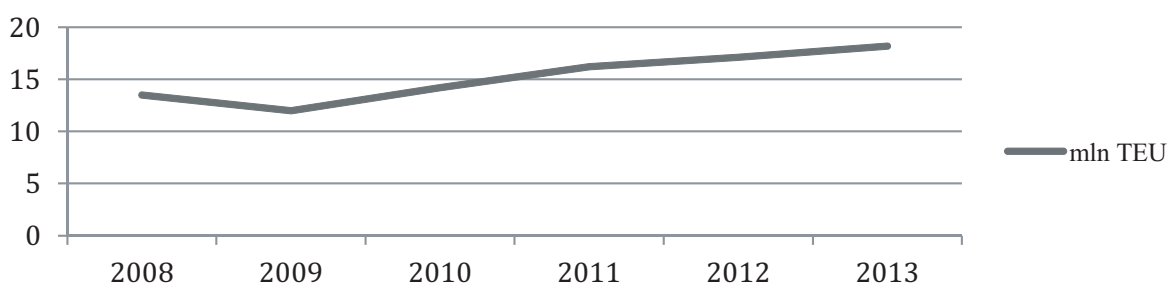

Figure 3. Busan Container Port 2008-2013

Source: author's calculations based on Jin-Sun-Shin, Northeast Asia Trade and Busan Container Port 2014, pp. 12-13

Market Share

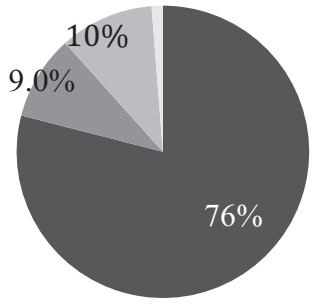

Busan

Incheon

Gwangyang

Inni

Figure 4. Domestic Market Share / Busan Ports Share

Source: author's calculations based on Jin-Sun-Shin, Northeast Asia Trade and Busan Container Port 2014, p. 14

SWOT $^{9}$ analysis (see Table 3 ) indicates the strengths of the port and the opportunities offered by the economic development of Asia and the specific risks arising from Chinese ports ${ }^{10}$.

${ }^{8}$ Twenty-Foot Equivalent Unit (TEU).

${ }^{9}$ SWOT analysis it the tool by which one can analyse and recognize Strengths and Weaknesses as well as the existing potential Opportunities and Threats coming from the business environment.

${ }^{10}$ Out of the 10 largest ports in the world, eight container ports are in China. 
Pobrane z czasopisma Annales H - Oeconomia http://oeconomia.annales.umcs.pl

Data: 26/04/2023 15:47:21

THE ROLE OF THE PORT OF BUSAN IN SOUTH KOREA INTERNATIONAL LOGISTICS

Table 3. SWOT Analysis Busan port

\begin{tabular}{|c|c|}
\hline Strengths & Weaknesses \\
\hline $\begin{array}{l}\text { - Fixed investment; } \\
\text { - A large number of logistic enterprises; } \\
\text { - Time of use; } \\
\text { - Location; } \\
\text { - Availability of rail-road infrastructure; } \\
\text { - The region as an adding value cluster; } \\
\text { - Price competitiveness; } \\
\text { - Well qualified staff availability. }\end{array}$ & $\begin{array}{l}\text { - No water connections to the hinterland; } \\
\text { - Large movement between the sub-ports. }\end{array}$ \\
\hline Opportunities & Threats \\
\hline $\begin{array}{l}\text { - Increasing participation in the international handling of goods } \\
\text { in the Southeast Asian region; } \\
\text { - Increasing exports of Korean companies; } \\
\text { - Development of tourism in Busan; } \\
\text { - Development of Asia - Europe railway connection; } \\
\text { - Consistent development of the northern port and the new port; } \\
\text { - Further weakening of the position of Japanese ports. }\end{array}$ & $\begin{array}{l}\text { - Growing strength of Chinese ports; } \\
\text { - Another financial crisis; } \\
\text { - Increasing labour costs; } \\
\text { - Possible conflicts between local and re- } \\
\text { gional authorities; } \\
\text { - Need to maintain balance between the de- } \\
\text { velopment of the port and the environment. }\end{array}$ \\
\hline
\end{tabular}

Source: own calculations based on: Y. Lee, Vision and Strategies of Busan: Development of the city into the ocean capital in the 21 st century of the ERA of the Northeast Asia p. 2

\section{Conclusion}

The process of globalization in north-east Asia has contributed to the understanding of the role of logistics and logistic infrastructure development in the construction of a competitive economy. In order to join the international and global logistic networks, it is not only an efficient infrastructure that is needed, but also legal and economic instruments which will boost economic potential. The level of infrastructure development, liberalization of the sector of services and trade determine the position of the port (country) on the map of the world logistics. In this context, the Republic of Korea is a positive example of development. The port of Busan has a good chance of becoming a logistic gateway to Northeast Asia. Main advantages of the port of Busan are shown in Chart 2.

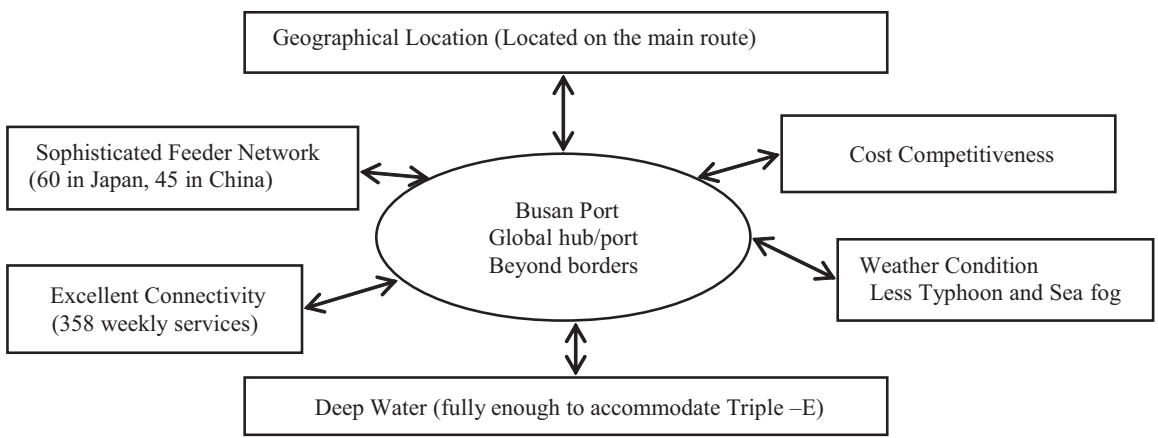

Chart 2. Main Strengths of Busan Port

Source: own calculations based on Jin-Sun-Shin, Northeast Asia Trade and Busan Container Port 2014, p. 17 


\section{References}

1. Antonowicz M., Globalizacja jako czynnik wplywu na rozwój logistyki na przykładzie wspólnoty ASEANU ed. [in:] E. Gołembska, Z. Bentyn, Logistyka międzynarodowa w zmiennych warunkach gospodarki światowej, Wydawnictwo Uniwersytetu Ekonomicznego w Poznaniu, Poznań, 2014.

2. Busan Economic Promotion Agency Busan International Promotion Centre: http://www.bifc.kr/eng/ sub02/sub02_01.asp [Date of access: December 1, 2015].

3. Coyle J., Bardi E., Langley J., 2002, Zarządzanie Logistyczne, PWE, Warszawa, 2002.

4. Cziomer E., Globalizacja a stosunki międzynarodowe, [in:] T. Wawaka, Zmieniajace się przedsiębiorstwo w zmieniajacej politycznie Europie, Vol. 3, Wydawnictwo Informacji Ekonomicznej, Uniwersytet Jagielloński, Kraków, 2000.

5. Ducruet C., Sung-Woo L., Centrality and vulnerability in liner shipping networks: revisiting the Northeast Asian port hierarchy, Maritime Policy and Management, 2006, Vol. 37.

6. Economic and Social Commission for Asia and The Pacific (ESCAP), Development of shipping and ports in NORTH-EAST Asia, United Nations, New York, 2005.

7. Encyclopaedia Britannica: http://www.britannica.com/EBchecked/topic/484254/Pusan [Date of access: October 24, 2014].

8. Gołembska E., Szymczak, M., Logistyka Międzynarodowa, PWE, Warszawa, 2004, No. 1.

9. Gołembska E., Logistyka międzynarodowa, PWE Warszawa, 2014.

10. Gołembska E., Szczyt M., Czynniki stymulujące rozwój logistyki międzynarodowej w warunkach zmienności gospodarki światowej. ed. [in:] E. Gołembska, Z. Bentyn, Logistyka międzynarodowa w zmiennych warunkach gospodarki światowej, Wydawnictwo Uniwersytetu Ekonomicznego w Poznaniu, Poznań, 2014.

11. Hayuth Y., Fleming D.F., Concepts of Strategic Commercial Location the Case of Container Ports, 1994.

12. inzynieria.com, http://drogi.inzynieria.com/cat/19/art/35582/lista-najwiekszych-morskich-portow kontenerowych\#ixzz3NxQzFzw3 [Date of access: December 5, 2015].

13. Korean International Trade Association. Logistic in Korea - Emerging Investment Opportunities. MLTM, 2009.

14. Koźmiński K. A., Zarządzanie międzynarodowe, PWE, Warszawa, 1999.

15. Lee Y., Vision and Strategies of Busan: Development of the city into an ocean capital in the 21st century of the ERA of the Northeast Asia p. 2 http://www.oecd.org/gov/regional-policy/6101010.pdf

16. Łatuszyńska M., Modelowanie międzynarodowych korytarzy transportowych, "Ekonomika i Organizacja Przedsiębiorstwa". Warszawa, 2004, No. 1.

17. Miklińska J., Koncepcja centrum Logistycznego - ujęcie statyczne, ed. [in:] M. Mindur, Logistyka -Infrastruktura logistyczna na świecie, PIB, Warszawa-Radom, 2008.

18. Mindur M., Centra logistyczne w Republice Korei, ed. [in:] M. Mindur, Logistyka - Infrastruktura logistyczna na świecie, PIB, Warszawa-Radom, 2008.

19. Murphy P., Wood D., Nowoczesna logistyka, Wydawnictwo HELION, Gliwice, 2011.

20. OECD official website, http://www.oecd.org/economy/korea-economic-forecast-summary.htm [Date of access: May 20, 2014].

21. Report, The Logistics Performance Index and Its Indicators, The Word Bank, 2014.

22. Report, Export of products and services 1960-2013, source: http://databank.worldbank.org/data/home. aspx [Date of access: December, 15 2014].

23. Rymarczyk J., Biznes międzynarodowy, PWE, Warszawa, 2012.

24. Szymczak M., Rozwój Łańcuchów dostaw, ed. [in:] M. Szymczak, Offshoring a rozwój łańcuchów dostaw, Wydawnictwo Uniwersytetu Ekonomicznego, Poznań, 2014.

25. Wielądek A., Korytarze transportowe, ed. [in:] L. Mindur, Technologie transportowe, IteE-PIB, Warszawa-Radom, 2014. 


\section{The role of the Port of Busan in South Korea international logistics}

Abstract. The authors in their article delineate the position of the Republic of Korea and the port of Busan on a logistic map of the world. They point out the port's fundamental success factors together with past actions which allowed Busan to become a logistic centre of north-east Asia. In particular, the authors emphasize the role of the strategic location of the port in the transport corridors. Reflections on the role of the port of Busan are illustrated through statistics and rankings created by institutions of global importance, e.g. The World Bank and the OECD.

\section{Rola Portu Busan w logistyce międzynarodowej Korei Południowej}

Abstrakt. Autorzy w swoim artykule kreślą pozycję Republiki Korei i portu Busan na mapie logistycznej świata. Wskazują na podstawowe czynniki sukcesu portu Busan i wysiłki jakie są podejmowane dla osiągniecia pozycji najważniejszego centrum logistycznego w Azji Północnowschodniej. Szczególnie autorzy podkreślają rolę strategicznej lokalizacji portu w korytarzach transportowych. Rozważania o roli portu Busan obrazują danymi statystycznymi oraz ocenami instytucji o światowym znaczeniu np. Banku Światowego czy OECD. 